\title{
Preparation and Some Properties of Nylon 46
}

\author{
R. J. GAYMANS, T. E. C. VAN UTTEREN, J. W. A. VAN DEN BERG, and \\ J. SCHUYER, Twente University of Technology, P.O. Box 217, Enschede, . \\ The Netherlands
}

\section{Synopsis}

Nylon 46 was synthesized from the salt of 1,4-diaminobutane and adipic acid. High molecular weight polymers could be obtained by reaction for $1 \mathrm{hr}$ at $215^{\circ} \mathrm{C}$ in a closed system and at least for $1 \mathrm{hr}$ in vacuo at a temperature in the range $290-305^{\circ} \mathrm{C}$. The reactions at $290^{\circ} \mathrm{C}$ were found to have taken place in the solid state and those at $305^{\circ} \mathrm{C}$ in the melt. The highest molecular weights $\left(\bar{M}_{w}\right.$ ca. 45,000 ) were obtained by reaction at $290^{\circ} \mathrm{C}$ with a nylon salt with a pH of 7.8-8.0. The molecular weight characteristics were studied with end-group analysis, viscometry, light scattering, and ultracentrifugation. The polymers were found to be gel-free and monodisperse $\left(\bar{M}_{w} / \bar{M}_{n} \sim 1.15\right)$. Films could be cast from formic acid. From x-ray diffraction patterns, measured on such films, spacings of 3.74 and $4.30 \AA$ were calculated, whereas a long period of $66 \AA$ was also found. The infrared spectra showed all the usual amide bands of even-even polyamides. The melting temperature was found to vary between 283 and $319^{\circ} \mathrm{C}$, depending on the thermal history of the sample. Water absorption measured on a cast film showed this to be very hygroscopic $(7.5 \%$ at $65 \% \mathrm{RH})$, while a highly crystalline sample absorbed only little water $(1.6 \%$ at $65 \% \mathrm{RH})$.

\section{INTRODUCTION}

Nylon 46 has a symmetrical molecular structure and a fairly high amide content:

$$
+\mathrm{NH}-\left(\mathrm{CH}_{2}\right)_{4}-\mathrm{NH}-\mathrm{CO}-\left(\mathrm{CH}_{2}\right)_{4}-\mathrm{CO}+n
$$

Consequently, properties like crystallinity and tensile strength should be at least comparable with those of nylon 66 or, possibly, even better with respect to practical uses. Surprisingly, rather little is known about synthesis and properties of nylon 46.

Carothers ${ }^{1}$ mentioned nylon 46 as early as 1938 . He reported a melting point of $278^{\circ} \mathrm{C}$, which was confirmed by Coffman et al..$^{2}$ ten years later. Beaman and Cramer ${ }^{3}$ found for the bulk polymer a melting point of $308^{\circ} \mathrm{C}$ and for a melt-spun fiber $283^{\circ} \mathrm{C}$. Their product has been synthesized by a two-step meltpolymerization process. The inherent viscosity $\eta_{\text {inh }}$ was 0.84 in a $0.5 \%$ solution in $m$-cresol at $30^{\circ} \mathrm{C}$. They reported also some film and fiber properties of nylon 46.

Ke et al. ${ }^{4}$ described the synthesis of some polyamides by interfacial polymerization. Their nylon 46 had a melting point of $293^{\circ} \mathrm{C}$. More recently Aubineau et al. ${ }^{5}$ prepared nylon 46 from adipoyl chloride in chloroform solution ( $\eta_{\text {inh }}$ was 0.48 in a $0.5 \%$ solution in $96 \%$ sulfuric acid).

One of the reasons for the little attention which this polymer got might be the difficulty of synthesizing a high molecular weight product. The melt polymer- 
ization of nylon 46 is rather difficult, because of the high melting point. During the reaction, oxidative and thermal degradation may occur as well as cyclization of 1,4-diaminobutane to pyrrolidine [eq. (1)].

$$
\mathrm{H}_{2} \mathrm{~N}-\left(\mathrm{CH}_{2}\right)_{4}-\mathrm{NH}_{2} \rightarrow \underset{\mathrm{H}}{\mathrm{H}_{2} \mathrm{C}} \prod_{\mathrm{N}^{\prime}-\mathrm{CH}_{2}}^{\mathrm{H}}+\mathrm{NH}_{3}
$$

Interfacial polymerization of this polymer is not as easy as that of the longer-chain polyamides 66 and 610 . Due to its hydrophilic nature, 1,4-diaminobutane is highly soluble in water but much less so in the second solvent which is required. Thus, the ratio of the concentration of diaminobutane in water to that in the second solvent is high. Consequently, the reaction is slow, so that hydrolysis of the acid chloride may occur. ${ }^{6}$ Solution polymerization is interesting only when the acid hydrochloride can be efficiently extracted.

In this report, we will present the results of a study of the preparation of nylon 46 by melt polymerization and some properties of this polymer.

\section{EXPERIMENTAL}

\section{Polymerization}

Nylon 46 salt was prepared in ethanol as described for the nylon 66 salt, and the $\mathrm{pH}$ of a $1 \%$ solution in water was determined. ${ }^{7}$ This $\mathrm{pH}$ of the salt is an easy measurable variable, depending on the excess of diamine present in the salt. 1,4-Diaminobutane (Baker \& Co.) was purified by distillation $\left(159^{\circ} \mathrm{C} / 760 \mathrm{~mm}\right.$ $\mathrm{Hg}$ ). Adipic acid (Fluka, purum) was used without further purification. The polymer was prepared from the salt by the method described for nylon $66,{ }^{7}$ but instead of a Carius tube we used the "capsule in autoclave" technique. ${ }^{8}$ The glass capsule has a breakseal which could be broken without opening the autoclave. The steel autoclave had a manometer, temperature control, and nitrogen feed, and it could be evacuated.

In a typical preparation, a thin-walled glass capsule (vol. $50 \mathrm{ml}$ ) was filled with $5 \mathrm{~g}$ of freshly prepared nylon $46 \mathrm{salt}$, purged of air, and sealed under vacuum. The sealed capsule was placed in an autoclave $(250 \mathrm{ml})$. After closing and purging, the autoclave was filled with nitrogen to a pressure of $20 \mathrm{~atm}$. It was heated for $2 \mathrm{hr}$ at $215^{\circ} \mathrm{C}$, while the pressure in the autoclave had increased to 40 atm. After the first step, it was allowed to cool to $40^{\circ} \mathrm{C}$ and the breakseal was broken by rocking the capsule against the lid (a pressure drop was observed on the manometer). The whole system was then evacuated $(0.5 \mathrm{~mm} \mathrm{Hg})$, and heated in vacuo for $1 \mathrm{hr}$ at a temperature in the range $290-305^{\circ} \mathrm{C}$.

\section{Characterization}

Amine end groups were determined by conductometric titrations in phenol/ water at $22^{\circ} \mathrm{C}, 9^{9}$ and carbonyl end groups by potentiometric titrations in benzyl alcohol at $200^{\circ} \mathrm{C} .{ }^{10}$ The inherent viscosities $\eta_{\text {inh }}$ were determined in $0.5 \%$ solution in $98 \%$ formic acid. 
For light-scattering measurements a Fica 50 instrument was used. Solutions $2.3 \mathrm{M}$ in $\mathrm{KCl}$ in $90 \%$ formic acid were prepared, this solvent mixture being known as a theta solvent for most nylons. ${ }^{11,12}$

The ultracentrifuge measurements were measured with a Spinco model $\mathbf{E}$ analytical ultracentrifuge on $0.4 \%$ solutions in $90 \%$ formic acid containing $2.3 M$ KCl. By means of the sedimentation-diffusion equilibrium method of Scholte, ${ }^{11}$ we determined $\bar{M}_{n}, \bar{M}_{w}$, and $\bar{M}_{z}$. The buoyancy factor $(1-\bar{v} d=-0.086)$ necessary for the calculation of these molecular weights from ultracentrifugation data was measured by means of a PEER DMA/50 digital density meter.

The melting behavior was studied with a Perkin-Elmer DSC-1B instrument at a heating rate of $16^{\circ} \mathrm{C} / \mathrm{min}$. The peak temperatures were taken as melting points.

Films were cast from formic acid solutions. The infrared spectra were obtained from thin films.

The water absorption was measured on samples which were first dried to constant weight in a vacuum oven at $80^{\circ} \mathrm{C}$, and then allowed to pick up water (1 day conditioning) at $23^{\circ} \mathrm{C}$, in successive atmospheres of $34,50,60,84$ and $100 \%$ $\mathrm{RH}$, maintained in a climate chamber equipped with a balance.

\section{RESULTS AND DISCUSSION}

\section{Polymerization}

The polymerization was carried out in two steps. After the first step ( $1 \mathrm{hr}$ at $215^{\circ} \mathrm{C}$ in a closed capsule), the polymer had an inherent viscosity of 0.18 (sample I) (Table I). High molecular weight polymer was obtained by reacting in the second step for $1 \mathrm{hr}$ at $290-305^{\circ} \mathrm{C}$ in vacuo. Under these conditions, reactions at $290^{\circ} \mathrm{C}$ were found to have taken place in the solid state and the reactions at $305^{\circ} \mathrm{C}$ in the melt. 1,4-Diaminobutane should be present in excess, as it is more

TABLE I

Reaction Conditions and Properties of Samples

\begin{tabular}{|c|c|c|c|c|c|c|c|c|c|c|}
\hline \multirow[b]{2}{*}{ Sample } & \multirow[b]{2}{*}{$\begin{array}{c}\text { Amt, } \\
\text { g }\end{array}$} & \multirow[b]{2}{*}{$\begin{array}{l}\text { pH } \\
\text { salt }\end{array}$} & \multirow[b]{2}{*}{$\begin{array}{c}\text { Extra } \\
\text { additives }\end{array}$} & \multicolumn{2}{|c|}{$\begin{array}{c}\text { Step } 1 \\
\text { (closed system) } \\
\end{array}$} & \multicolumn{2}{|c|}{$\begin{array}{l}\text { Step } 2 \\
\text { (vacuum) }\end{array}$} & \multirow{2}{*}{$\begin{array}{c}\text { Physical } \\
\text { state } \\
\text { during } \\
\text { reaction } b\end{array}$} & \multirow[b]{2}{*}{$\begin{array}{c}\eta_{\mathrm{inh}} \\
\mathrm{dl} / \mathrm{g}\end{array}$} & \multirow[b]{2}{*}{ Color } \\
\hline & & & & $\begin{array}{l}\text { Temp, } \\
{ }^{\circ} \mathrm{C}\end{array}$ & $\begin{array}{c}\text { Time, } \\
\text { hr }\end{array}$ & $\underset{{ }^{\circ} \mathrm{C}}{\text { Temp }}$ & $\underset{\mathrm{hr}}{\mathrm{Time}}$ & & & \\
\hline I & 5 & 7.6 & - & 220 & 1 & - & - & & 0.18 & colorless \\
\hline II & 5 & 7.2 & - & 220 & 1 & 290 & 1 & $\mathbf{s}$ & 1.34 & light yellow \\
\hline III & 5 & 7.4 & - & 220 & 1 & 290 & 1 & $\mathbf{s}$ & 1.32 & light yellow \\
\hline IV & 5 & 7.6 & - & 220 & 1 & 290 & 1 & s & 1.69 & light yellow \\
\hline V & 5 & 7.8 & - & 220 & 1 & 290 & 1 & $\mathbf{s}$ & 2.01 & light yellow \\
\hline VI & 5 & 8.0 & - & 220 & 1 & 290 & 1 & $\mathbf{s}$ & 1.99 & light yellow \\
\hline VII & 5 & 8.3 & - & 220 & 1 & 290 & 1 & $\mathbf{s}$ & 2.09 & light yellow \\
\hline VIII & 5 & 7.2 & - & 220 & 1 & 305 & 1 & $\mathbf{m}$ & 1.29 & yellow \\
\hline IX & 5 & 7.4 & - & 220 & 1 & 305 & 1 & $\mathrm{~m}$ & 1.45 & yellow \\
\hline $\mathbf{x}$ & 5 & 7.6 & - & 220 & 1 & 305 & 1 & $m$ & 1.65 & yellow \\
\hline XI & 5 & 7.7 & - & 220 & 1 & 305 & 1 & $\mathrm{~m}$ & 1.56 & yellow \\
\hline XII & 5 & 7.8 & - & 220 & 1 & 305 & 1 & $\mathbf{m}$ & 1.54 & yellow \\
\hline XIII & 5 & 7.8 & - & 220 & 1 & 305 & 1 & $m$ & 1.55 & yellow \\
\hline XIV & 60 & 7.6 & - & 220 & 2 & $\begin{array}{l}280 \\
290\end{array}$ & $\begin{array}{l}2 \\
2\end{array}$ & $\mathbf{s}$ & 1.72 & light yellow \\
\hline $\mathrm{XV}$ & 60 & 7.6 & $\begin{array}{c}\text { AA, } 1.25 \% \\
\text { TDMA } \\
0.62 \%\end{array}$ & 220 & 2 & $\begin{array}{l}280 \\
290\end{array}$ & $\begin{array}{l}2 \\
2\end{array}$ & $\mathbf{s}$ & 1.03 & colorless \\
\hline
\end{tabular}

${ }^{\mathrm{a}} \mathrm{AA}=$ adipic acid; $\mathrm{TDMA}=$ tetramethyl diammonium acetate.

$b_{S}=$ solid state $; m=$ melt . 


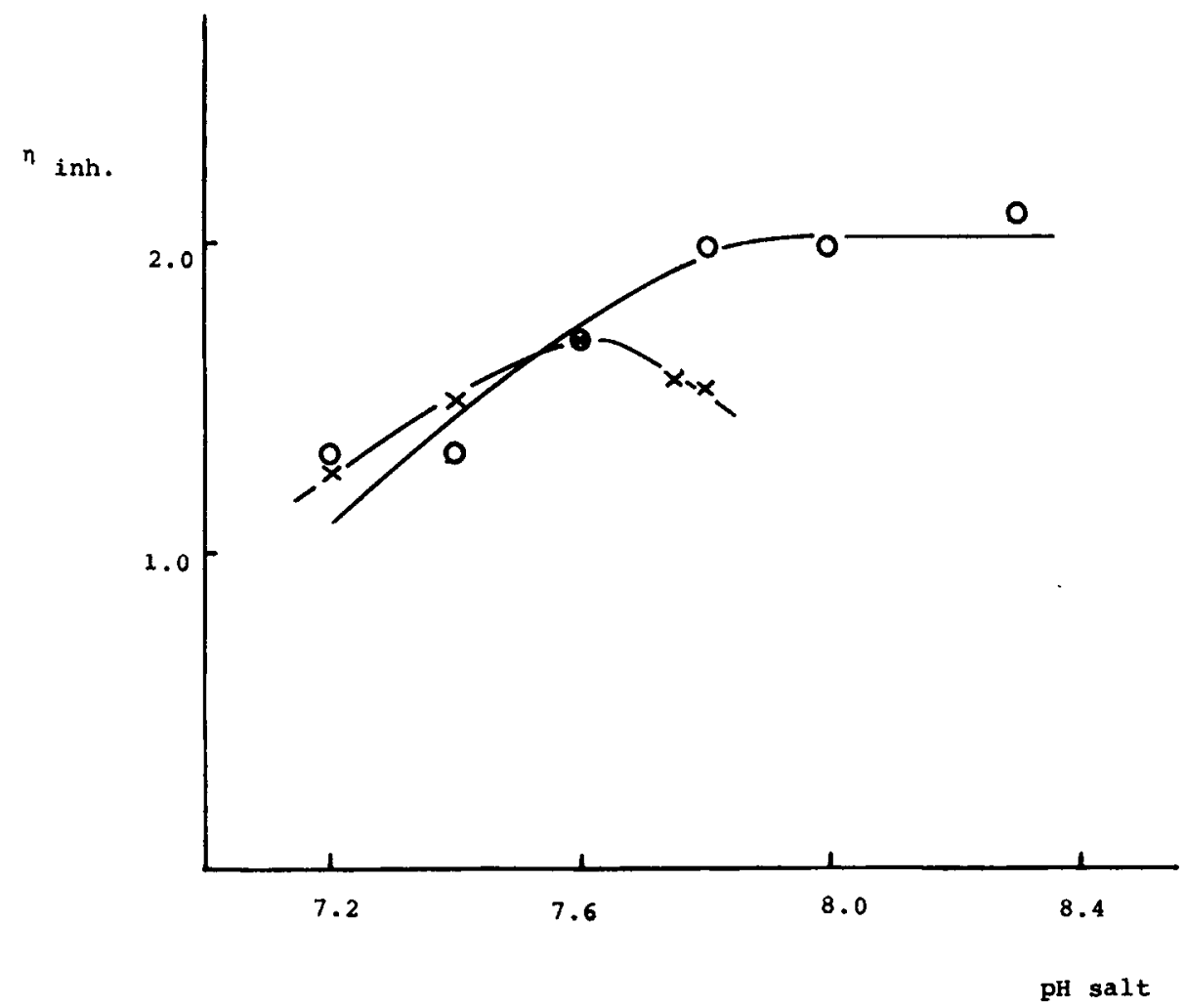

Fig. 1. Influence of the salt $\mathrm{pH}$ on $\eta_{\mathrm{inh}}$ of the polymers prepared: (x) sample polymerized at $308^{\circ} \mathrm{C}$ in the melt; (O) sample polymerized at $290^{\circ} \mathrm{C}$ in the solid state.

volatile than adipic acid and can cyclize to pyrrolidine. In order to study the effect of excess diaminobutane, starting salts with variable $\mathrm{pH}$ (1\% solution in water) were prepared. The polymers prepared at $290^{\circ} \mathrm{C}$ (in the solid state) had a maximum in $\eta_{\text {inh }}$ when the $\mathrm{pH}$ of the salt was 7.8-8.3 (Table I, Fig. 1). The polymers prepared at $305^{\circ} \mathrm{C}$ (in the melt) had a lower maximum in $\eta_{\text {inh }}$ at a lower salt $\mathrm{pH}$ (7.6). In the $\mathrm{pH}$ range 7.2-7.6 there is no detectable difference in $\eta_{\text {inh }}$ between the polymers prepared at $290^{\circ} \mathrm{C}$ and $305^{\circ} \mathrm{C}$. Under the reaction conditions used $\left(290-305^{\circ} \mathrm{C}\right.$, in vacuo), nylon 66 would normally form branched structures and gels. ${ }^{13,14}$ Therefore, we studied the molecular weight characteristics of samples II-VII in detail (Table II).

TABLE II

Characterization Data

\begin{tabular}{|c|c|c|c|c|c|c|c|c|c|}
\hline & \multirow[b]{2}{*}{$\mathrm{pH}$} & \multirow[b]{2}{*}{$\begin{array}{r}\eta_{\text {inh }}, \\
\mathrm{dl} / \mathrm{g}\end{array}$} & \multicolumn{3}{|c|}{$\begin{array}{l}\text { End-group analysis, } \\
\text { ends } / 10^{6} \mathrm{~g}\end{array}$} & \multirow{2}{*}{$\begin{array}{c}\text { Light } \\
\text { scattering } \\
\bar{M}_{w}\end{array}$} & \multicolumn{3}{|c|}{ Ultracentrifugation } \\
\hline & & & $-\mathrm{NH}_{2}$ & $-\mathrm{COOH}$ & $\bar{M}_{n}$ & & $\bar{M}_{n}$ & $\bar{M}_{w}$ & $\bar{M}_{z}$ \\
\hline II & 7.2 & 1.34 & 5.3 & 60.3 & 31,000 & 23,000 & 27,000 & 30,000 & 35,000 \\
\hline III & 7.4 & 1.32 & 8.6 & 53.9 & 32,000 & 22,000 & - & - & - \\
\hline IV & 7.6 & 1.69 & 10.1 & 32.7 & 47,000 & 31,000 & 30,000 & 34,000 & 39,000 \\
\hline V & 7.8 & 2.01 & 16.1 & 21.5 & 53,000 & 43,000 & - & - & - \\
\hline VI & 8.0 & 1.99 & 14.2 & 23.6 & 53,000 & 40,000 & 37,000 & 42,000 & 49,000 \\
\hline VII & 8.3 & 2.09 & 40.3 & 9.7 & 40,000 & 47,000 & - & - & - \\
\hline
\end{tabular}





$\alpha$-form triclinic chains parallel

$\beta$-form monoclinic chains anti-parallel

Fig. 2. Schematic view of two possible crystal arrays in nylon 46 .

The $\bar{M}_{n}$ obtained from end-group analysis is found to be higher than the $\bar{M}_{w}$ from light scattering. Thus, it seems that with our end-group analysis not all end groups were determined. This is confirmed by the ultracentrifugation measurements of $\bar{M}_{n}$ for II, IV, and VI. The $\bar{M}_{w}$ determined by light scattering gave similar increases with the $\mathrm{pH}$ of the salt as $\eta_{\text {inh }}$. No bottom layer was observed during ultracentrifugation runs, and from this we can conclude that no gel was present in the samples studied. Moreover, the polydispersity was found to be surprisingly low $\left(\bar{M}_{w} / \bar{M}_{n} \sim 1.15\right)$. This suggests that no branched structures or gels were formed during the high-temperature polymerization in vacuo.

We can explain this difference between nylon 46 and nylon 66 synthesis as follows. For nylon 66, one of the important steps in the formation of a gelled structure is the formation of the trifunctional dimer of 1,6-diaminohexane [eq. (2)]. ${ }^{13,15}$ 

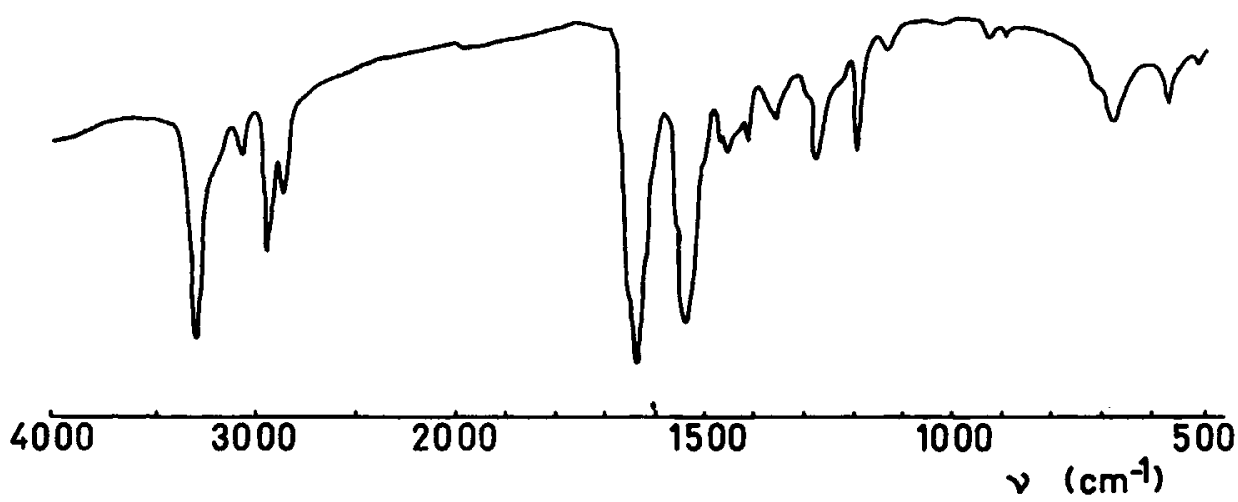

Fig. 3. Infrared spectrum of a solution-cast film.

$$
2 \mathrm{H}_{2} \mathrm{~N}-\left(\mathrm{CH}_{2}\right)_{6}-\mathrm{NH}_{2} \rightarrow \mathrm{H}_{2} \mathrm{~N}-\left(\mathrm{CH}_{2}\right)_{6}-\mathrm{NH}-\left(\mathrm{CH}_{2}\right)_{6}-\mathrm{NH}_{2}+\mathrm{NH}_{3}
$$

The formation of a similar dimer from 1,4-diaminobutane is less likely, as it has a strong tendency to react with its own amine group and cyclize to pyrrolidine.

Larger quantities of polymer could easily be prepared with the same method (XIV, XV). Sample XV was synthesized in the presence of the additives adipic acid and tetramethylene diammonium acetate. ${ }^{2}$

The "capsule in autoclave" method has the advantage of being a safe and simple technique of conducting the first step in a closed system at high temperatures and high pressures and conducting the second step in vacuo under good oxygen-free conditions.

\section{Structure Analysis}

Nylon 46 has a symmetrical structure and should be able to form, in analogy with nylon $7,{ }^{16}$ a triclinic parallel structure and a monoclinic antiparallel structure (Fig. 2). Both structures might occur simultaneously. It is expected that the crystallinity will be high.

TABLE III

Main Bands in the Infrared Spectrum of Cast Film

\begin{tabular}{|c|c|c|}
\hline $\begin{array}{l}\text { Band, } \\
\mathrm{cm}^{-1}\end{array}$ & Intensity $^{a}$ & Assignment \\
\hline 3300 & vs & N-H band \\
\hline 3070 & m & $\mathrm{N}-\mathrm{H}$ band \\
\hline 2945 & $\mathbf{s}$ & $\mathrm{C}_{\mathrm{H}_{2}-}^{-}$ \\
\hline 2870 & m & $\mathrm{C}_{\mathrm{H}_{2}}-$ \\
\hline 1638 & vvs & amide I \\
\hline 1540 & vvs & amide II \\
\hline 1280 & $\mathbf{m}$ & amide III \\
\hline 940 & $\mathbf{w}$ & amide IV \\
\hline 730 & sh & amide V ( $\gamma$-structure) \\
\hline 690 & s (broad) & amide $V(\alpha$-en $\beta$-structure) \\
\hline 575 & m & amide VI \\
\hline 520 & $\mathbf{w}$ & amide VI \\
\hline
\end{tabular}

a Intensity: $v s=$ very strong; $m=$ medium; $s=$ strong; $v v s=$ very very strong; $w=$ weak; $s h=$ shoulder. 


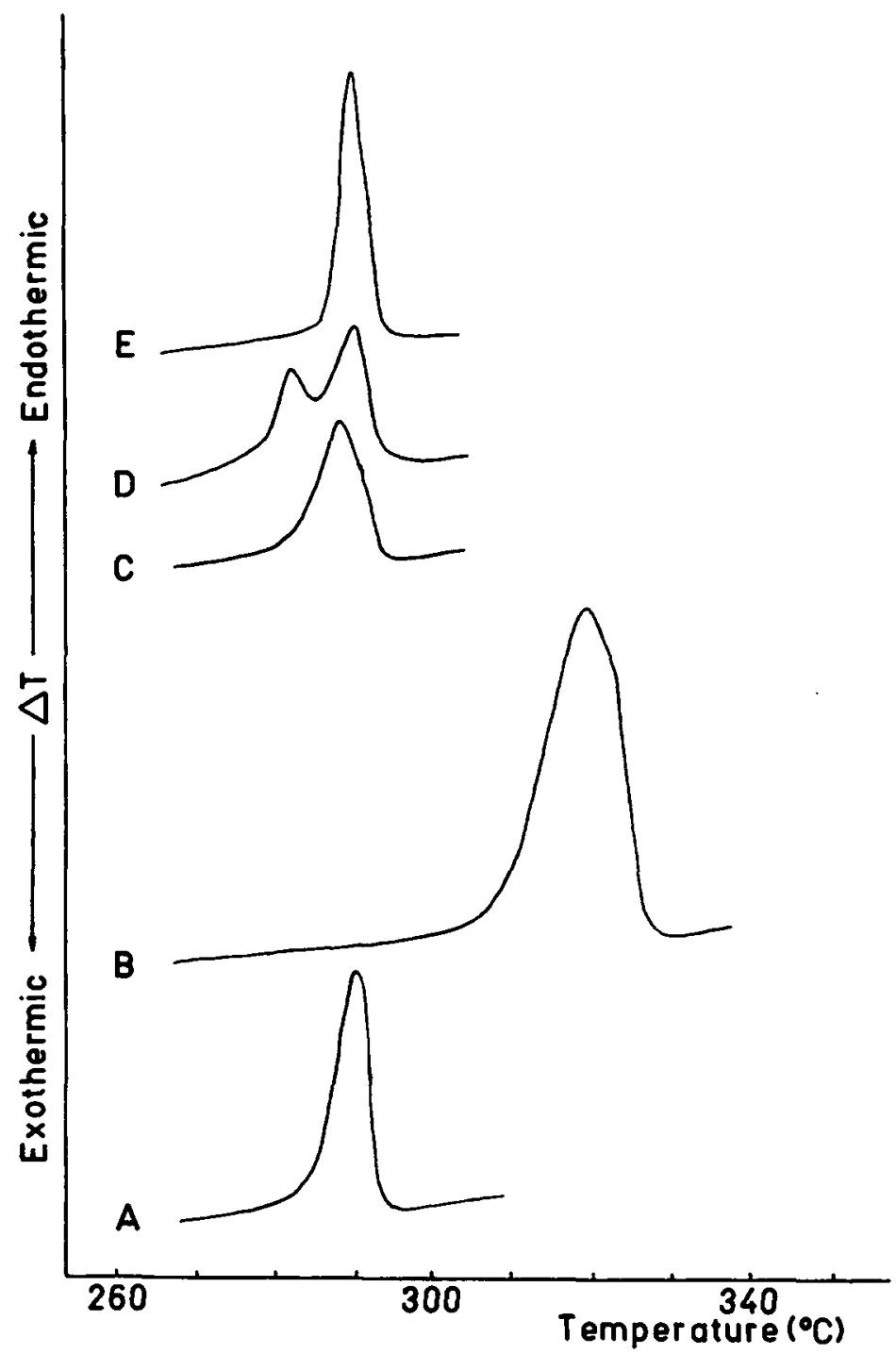

Fig. 4. DSC curves at $16^{\circ} \mathrm{C} / \mathrm{min}$ heating rate: $(A)$ melt-polymerized sample; $(B)$ sample polymerized in the solid state; $(C)$ cast film; $(D)$ quenched sample; $(E)$ sample, quenched and annealed for $5 \mathrm{~min}$ at $279^{\circ} \mathrm{C}$.

From x-ray studies on cast films of XIV, we found the following interplanar spacings: $d_{010}=3.74 \AA$, and $d_{100}=4.30 \AA$; a long period of $66 \AA$ was also found. These results are similar to those reported for other even-even polyamides with an $\alpha$-structure. ${ }^{17}$

The infrared spectra of the polymer XIV (Fig. 3, Table III) show amide bands at the frequencies of polyamides with an $\alpha$-structure. ${ }^{18,19}$

\section{Properties}

The most frequently quoted property of nylon 46 is its melting point, which ranges from 278 to $308^{\circ} \mathrm{C}$..$^{1-5}$ Particularly interesting is the finding of Beaman, ${ }^{3}$ who obtained a melting point of $308^{\circ} \mathrm{C}$ on the bulk polymer and a melting point of $283^{\circ} \mathrm{C}$ after melt spinning and drawing. Our melt-polymerized polymer $\mathrm{X}$ 
8 adsorbed water

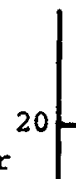


(Fig. $4 D$ ), but if a quenched sample was annealed for 5 min at $279^{\circ} \mathrm{C}$, a sharp single melting peak was obtained at $291^{\circ} \mathrm{C}$ (Fig. $4 E$ ).

These results show that the melting point is strongly dependent on the thermal history of the sample and can be changed reversibly. The shift to a higher melting temperature suggests an increase in the crystallite perfection or size. The sometimes observed double melting peak suggests the presence of another structure. The heats of fusion corresponding with the samples A-E were 15.7, $31.3,13.7,14.6$, and $15.1 \mathrm{~kJ} / \mathrm{mole}$, respectively. Samples which had previously been melted ( $A$ and $D$ ) gave results which seem to be dependent on the rate of cooling of the molten samples.

The density of a solid-state polymerized polymer was $1.24 \mathrm{~g} / \mathrm{cm}^{3}$ and that of a solution-cast film $1.20 \mathrm{~g} / \mathrm{cm}^{3}$. The polymer is rather difficult to dissolve. ${ }^{3} \mathrm{~A}$ good solvent is formic acid and, to a lesser extent, trifluoroacetic acid. Concentrations up to $45 \%$ polymer could be obtained in $98 \%$ formic acid. Even in $60 \%$ formic acid nylon 46 is soluble. Polyamides absorb water, the amount of which is strongly dependent on the amide group concentration ${ }^{20}$ and crystallinity. ${ }^{21}$

The highly crystalline sample XIV absorbed little water, while the cast film was very hygroscopic (Fig. 5).

The authors wish to thank Messrs. J. M. Alberigs and A. H. Pleiter for their assistance with the high-pressure experiments, and Mr. G. van de Ridder for molecular weight characterization of the samples.

\section{References}

1. W. H. Carothers, U.S. Pat. 2,130,948 (1938).

2. D. D. Coffman, G. J. Berchet, W. R. Peterson, and E. W. Spanagel, J. Polym. Sci., 2, 306 (1947).

3. R. G. Beaman and F. B. Cramer, J. Polym. Sci., 21, 223 (1956).

4. B. Ke and A. W. Sisko, J. Polym. Sci., 50, 87 (1961).

5. C. Aubineau, R. Audebert, and G. Champetier, Bull. Soc. Chim. France, 1970, 533.

6. P. W. Morgan, Condensation Polymers (Polymer Reviews, Vol. 10), Interscience, New York, 1965, Chapts. II and III.

7. D. F. Beck and E. E. Magat, in Macromolecular Synthesis, Vol. III, N. G. Gaylord, Ed., Wiley, New York-London, 1968, p. 101.

8. D. M. W. van den Ham, Chem. Ind. (London), 1972, 730.

9. G. B. Taylor, J. Amer. Chem. Soc., 69, 635 (1947).

10. J. E. Waltz and G. B. Taylor, Anal. Chem., 19, 448 (1947).

11. T. G. Scholte, J. Polym. Sci. A-2, 6, 91, 111 (1968).

12. H. G. Elias and R. Schumacher, Makromol. Chem., 76, 23 (1964).

13. G. H. Kroes, thesis, Univ. of Delft, 1963.

14. J. J. Burke and T. A. Orofino, J. Polym. Sci. A-2, 7, 1 (1969).

15. L. H. Peebles and M. W. Huffman, J. Polym. Sci. A-1,9, 1807 (1971).

16. W. P. Slichter, J. Polym. Sci., 36, 259 (1959).

17. A. Miyake, J. Polym. Sci., 44, 223 (1960).

18. I. Matsubara, Y. Ito, and M. Shinomiya, J. Polym. Sci. B, 4, 47 (1966).

19. I. Matsubara and J. H. Magill, J. Polym. Sci. Polym. Phys., Ed., 11, 1173 (1973).

20. A. Müller and R. Pflüger, Kunststoffe, 50, 203 (1960).

21. H. W. Starkweather, G. Moore, J. P. Hansen, T. M. Roder, and R. Brooks, J. Polym. Sci., 21, 189 (1956).

Received September 29, 1975

Revised April 11, 1976 